\title{
The Effect of Transformational Leadership, Work Culture, Self Learning and Work Commitment Towards Teacher's Performance
}

\author{
Lisa Gracia Kailola \\ Postgraduates of Educational Management Study Program \\ Universitas Kristen Indonesia, UKI \\ lisa.gracia@uki.ac.id
}

\begin{abstract}
Teacher's performance plays a crucial role in achieving quality of education and good character of students. Low teacher's performance will decrease quality of graduates itself. Based on data in Depok City, West Java, teacher's performance is in the priority programs of government, and still need to be Increased. The objectives of this study is to investigate whether there exists any direct positive effect of transformational leadership, work culture, self learning and work commitment towards teacher's performance at 19 Public Junior High Schools in Depok City, West Java. A total of 91 from 974 teachers were sampled to collect the data which was then analyzed using path analysis quantitative method. The result shows that there exists a positive direct effect of (1) transformational leadership towards teacher's performance, (2) work culture towards teacher's performance, (3) self-learning towards teacher's perfomance, (4) work commitment towards teacher's performance, (5) transformational leadership towards work commitment, (6) work culture towards work commitment, (7) self learning towards work commitment, (8) transformational leadership towards self learning, (9) work culture towards self learning, and (10) transformational leadership towards work culture.
\end{abstract}

Keyword-self learning, teacher's performance, transformational leadership, work commitment, work culture

\section{INTRODUCTION}

National education goals are educating the nation and developed a complete Indonesian man, the man who is faithful and devoted to God Almighty and noble character, knowledge and skills, physical and spiritual health, personality steady and independent, sense of responsibility of community and nationality.

One of the very important component in the development of education is the availability of adequate resources. The resources referred to in this case is the teacher. Teachers as the forefront in the development and educational services to the community. The effectiveness and efficiency of the teaching and learning of students in the school is very dependent on the teacher's role. This means that the role of teachers in education not only as an educator, but has a very diverse roles. At school, teachers act as designers of learning, learning manager, assessor of learning outcomes of learners, learning guides and mentors learners. Meanwhile, in the family, teachers act as an educator in the family (family educator). Meanwhile in the community, teachers act as a builder of society (social developer), inventor of the community (social innovators), and public agencies (social agent), and many more roles of teachers who make a profession as a teacher has a great responsibility. Therefore, the extent to which the quality of graduate students in a school, is highly dependent on the quality of the teacher. The teachers are required to be able to demonstrate a satisfactory performance in order to deliver an optimal contribution to the organization.

The policy to improve teacher performance is a major concern by City Government of Depok, West Java. The performance of teachers is a very important element in achieving the vision of a school. However, the state of teacher performance is still not as expected. It is seen from the data report released by the Ministry of Finance of the Republic of Indonesia Directorate General of Fiscal Balance in the Book Review of Economics and Finance of West Java Province in 2012, the educational background of the entire employee in the province of West Java are very varied from the just graduated from elementary to graduate College. The indicator of the learning quality that can be received by the student/junior high school students is a comparison of teaching students who taught by each teacher, which in the report of the Minister of Finance stated that student-teacher ratios in Depok is 87.20 students/teachers.

To meet the challenges of education in Depok, Depok City Government set out a number of educational budget, as contained in the budget document (DPA) in 2015 for education to improve the competence of teachers through Teacher Teaching Group and Teacher's Forum Discussion, workshops, training and debriefing of supervisors, management training based schools for School Principals and educational personnel, assessor training, and development of educational facilities. All the program aims to improve the quality of learning and education in the city of Depok. 
Based on the desctiption above, the researcher is interested doing this study to investigate whether there exists any direct posititve effect of transformational leadership, work culture, self learning and work commitment towards teacher's performance at Public Junior High School in Depok City, West Java.

Conceptually, performance is defined as the expected value in total by the organization of a series of real behavior committed by individuals during a certain time standards. The performance in the context of a person's job performance, individuals who have good performance will show the real action is the best he can do [1]. "All of the behaviors employees engage in while at work."[2] This definition insists that the performance is all the behavior of employees involved in the work. The performance is the behavior of the employees involved while at work that contributes to achieving organizational goals [2]. "Job performance as evaluatable behaviours"[3]. According to this concept, the performance means that behaviors can be evaluated. although he firmly using behavioral aspects to declare the performance, but no differences were quite sharp between the behavioral aspects and results in the concept of performance [3]. Furthermore, the concept of performance that highlights the outcomes described by Bernadin and Beatty, the performance means record the output generated in the function or activity during the period of time specified[3]. The definition that emphasizes results also stated by Bailey in Rothwell in Kazanaz [4], the performance is the result of a pattern of actions taken to satisfy the purpose in accordance with the standards. This is different from the behavior, which also means that action can be observed. The same performance as the result, while the behavior is the action to achieve results. The components of performance as a function of the three determinants, namely: (1) declarative knowledge, (2) procedural knowledge and skills, and (3) motivation[2].

Based on the description above, it can be synthesised that performance is the performance of a person in completing tasks and responsibilities based on ability and skill he has with the indicators used to measure performance are: (1) effectivity, (2) productivity, and (3) resultof the work.

\section{Transformational Leadership}

According to Burns, "transformational leadership can be seen when leaders and followers make each other to advance to higher levels of morale and motivation [5]. The essence of this theory is the followers feel the trust, admiration, loyalty and respect for leaders and they are motivated to do more than what was originally expected of them.Transformational leadership is a leader who has a vision for the future and be able to identify changes in the environment and is able to transform these changes into the organization; pioneered changes and provide motivation and inspiration to individuals employees to be creative and innovative, and to build a solid teamwork; bring a change in work ethic and performance management; brave and responsible to lead and control the organization [6]. Summed up the essence of transformational leadership is to empower followers to perform effectively by building commitment to the new values, develop skills and their confidence, create a climate conducive to the development of innovation and creativity [7]. Proposes four dimensions in the levels of personal leadership with the concept $4 \mathrm{i}$, which means: (a) Idealized Influence; (b) Inspirational Motivation; (c) Intellectual Simulation; (d) Individual Consideration [6]. "transformational leadershp serves to change the status quo followers by articulating the problems in the current system and a compelling vision of what the new organization could be"[8]. Bold transformational leadership conduct and respond to changes if necessary and explain to all employees about the benefits of the changes made according to the vision of the organization.

Based on the description above, it can be synthesized that transformational leadership is the leader's ability to influence his subordinates and have a willingness to work in achieving organizational goals that can be measured by indicators (1) the influence of idealism, (2) intellectual stimulation, (3) inspirational motivation and (4) individual consideration.

\section{Work Culture}

Culture is a whole system of ideas of action and a man's work in the context of a society that used had human self by learning, while work is a philosophy with based view of life as values into the nature, habits and also driving the civilized world in a group and be reflected in the attitudes of behavior, ideals, ideas, opinions and actions manifested as work. The work culture is very important to maximize the value of human resources and should be an important management competencies [9]. As part of the organization, Schein explains that organizational culture is assumptions and basic beliefs were shared with members of the organization [10]. Organizational culture is also a solution that can consistently run well for a group in the face of the problems of external and internal, so that it can be taught to new members as a perception, thinking and feeling in relation to her problems. The principles that underlie the emergence of workplace culture, such as: loyalty, respect, honesty, resonsibility, accountability, integrity, high-quality relationship among oraginzational member[8].

Based on the description above, it can be synthesized that work culture is a system of mutual understanding held by members of an organization that influence the behavior of its members in performing their duties and responsibilities in the organization and can be measured by indicators (1) motivation, (2) attitude and individual behavior; and (3) loyalty.

\section{Self Learning}

Knowles defines self learning, as a process in which individuals take the initiative, with or without the help of 
others, in diagnosing their learning needs, formulating learning goals, identifying human resources and materials for learning, select and implement strategies appropriate learning and evaluating learning outcomes[11]. In connection with the process of self learning, Zimmerman explains further that the self regulated learning can be grouped into three stages, namely stages: (1) initial thoughts; (2) control in the implementation or the will; (3) the stage of self-reflection [12]. Self learning as a constructive process when teachers set learning goals themselves while trying to monitor, manage, and control the observation of motivation, and behavior that is limited by the learning objectives and environmental conditions [12]. Self learning as the changes themselves are affected by events that occur in the work environment, personal factors, and behavior interact in the learning process[13]. Personal factors (beliefs, expectations, attitudes, and knowledge), social and physical environment (resources, consequences of actions, others and the physical setting) all affect each other and influenced the personal self. In connection with one's abilities, self learning is the ability to effectively manage their own learning experiences in a variety of ways to obtain optimal learning results[14].

Based on the description above, it can be synthesized that self learning is the efforts of individuals who carried out systematically to focus the mind, feelings, and behavior on the achievement of learning objectives are done on yourself by doing repairs on her conscious and planned, so as to encourage him (motivation) to develop into better define ways that support the development towards self-optimally, measured by indicators: (1) the self-assessment, (2) selfimprovement and (3) strengthening themselves.

\section{Work Commitment}

That commitment as a force that binds individuals to achieve the target (social or non-social) and for an act that is relevant to these objectives. Furthermore, in conjunction with work commitments, the work commitment is a function of personal characteristics including dispositional quality and design facets of the current work commitment that includes a work ethic, career commitment, organizational commitment and job involvement [15]. organizational commitment is related to the relative strength of a person and regarding his involvement in private organizations and can be characterized by their strong faith towards the goals and values of the organization, and to seek, and a strong desire to keep and the name of the organization's membership [16]. Commitment to work closely associated with job involvement. Work engagement can be defined as the degree to which people are known from his work, actively participate in it and considered an important achievement to self-esteem [17]. Employees who have a high level of work engagement that is strong will have a tendency to care about the kind of work he was doing and actively participate in and always try to understand (identify) any work given to him as well as possible in accordance with its capabilities.
Based on the description above, it can be synthesized that work commitment is engagement and behaviors that support in doing the job and can be measured by indicators (1) work ethic, (2) loyalty and (3) work engagement.

\section{METHOD}

The study uses a quantitative approach through path analysis survey method. This type of survey research focuses on disclosure of causal relationships between variables. The population in this study were 974 teachers Junior High School in Depok, where the sample is determined by random sampling of the population randomly numbered 91 people.

In this study, to collect data the researcher using questionnaires. Instruments tested before used in the study. The testing instrument covers the validity (validity) and reliability testing (reliability).

Data analysis of this study is descriptive and inferential analysis. Descriptive analysis is used in the presentation of the data, the size of the central and the size of the deployment. Descriptive data analysis can be presented in the form of tables and histogram distribution. Inferential analysis was used to test the hypothesis that use path analysis, preceded by a test for normality, error estimates and regression analysis.

\section{RESULT AND DISCUSSION}

After normality test error estimates, then the hypothesis testing results obtained first image path coefficients.

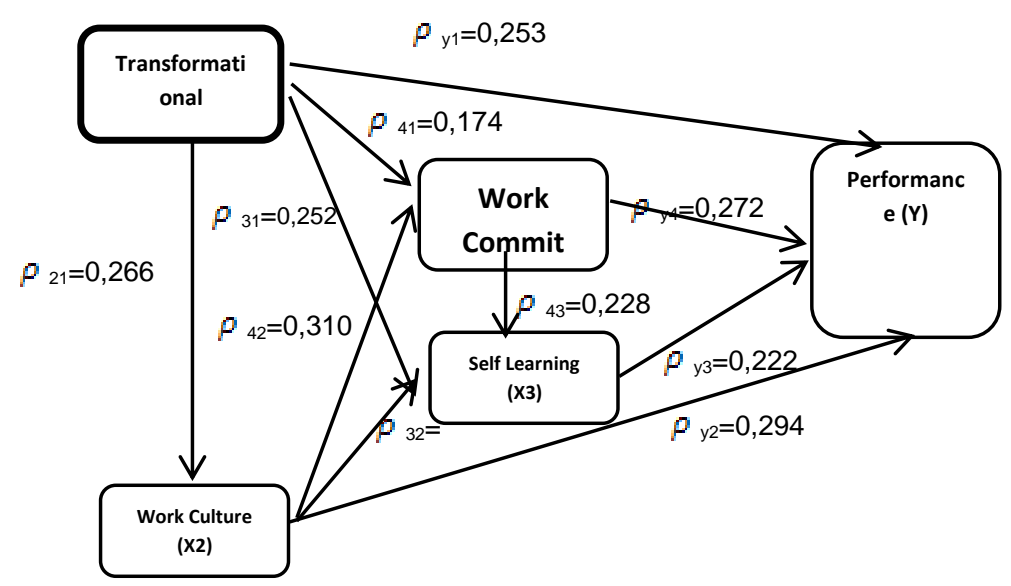

Figure 1.

Path coefficient Transformational Leadership, Work Culture, Self Learning, Work Commitment to Performance 
TABLE I. Hypothesis Testing Results

\begin{tabular}{|c|c|c|c|c|}
\hline Variable & $\begin{array}{c}\text { Coeffis } \\
\text { ient } \\
\text { Line }\end{array}$ & $\mathbf{t}$ & 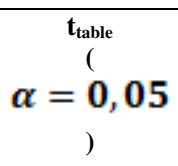 & Desicion \\
\hline$X_{1}$ to $Y$ & $\begin{array}{c}\rho_{y 1}=0 \\
, 253\end{array}$ & 3,182 & 1,66 & $\begin{array}{l}\mathrm{H}_{0} \text { is rejected, } \mathrm{H}_{1} \\
\text { accepted. There is } \\
\text { a direct positive } \\
\text { influence of } \\
\text { Transformational } \\
\text { Leadership }\left(\mathrm{X}_{1}\right) \text { to } \\
\text { Teacher } \\
\text { Performance }(\mathrm{Y})\end{array}$ \\
\hline $\mathrm{X}_{2}$ to $\mathrm{Y}$ & $\begin{array}{c}\rho_{y 2}=0 \\
, 294\end{array}$ & 3,586 & 1,66 & $\begin{array}{l}\mathrm{H}_{0} \text { is rejected, } \mathrm{H}_{1} \\
\text { accepted. There is } \\
\text { a direct effect of } \\
\text { the positive work } \\
\text { culture }\left(\mathrm{X}_{2}\right) \text { to } \\
\text { Teacher } \\
\text { Performance }(\mathrm{Y})\end{array}$ \\
\hline $\mathrm{X}_{3}$ to $\mathrm{Y}$ & $\begin{array}{c}\rho_{y 3}=0 \\
, 222\end{array}$ & 2,733 & 1,66 & $\begin{array}{l}\mathrm{H}_{0} \text { is rejected, } \mathrm{H}_{1} \\
\text { accepted. There is } \\
\text { a direct positive } \\
\text { influence Self } \\
\text { Learning }\left(\mathrm{X}_{3}\right) \\
\text { toTeacher } \\
\text { Performance (Y) }\end{array}$ \\
\hline $\mathrm{X}_{4}$ to $\mathrm{Y}$ & $\begin{array}{c}\rho_{y^{4}}=0 \\
, 272\end{array}$ & 3,185 & 1,66 & $\begin{array}{l}\mathrm{H}_{0} \text { is rejected, } \mathrm{H}_{1} \\
\text { accepted. There is } \\
\text { a direct positive } \\
\text { influence Work } \\
\text { Commitment }\left(\mathrm{X}_{4}\right) \\
\text { toTeacher } \\
\text { Performance }(\mathrm{Y})\end{array}$ \\
\hline$X_{1}$ to $X_{4}$ & $\begin{array}{c}\rho_{41}=0 \\
, 174\end{array}$ & 1,778 & 1,66 & $\begin{array}{l}\mathrm{H}_{0} \text { is rejected, } \mathrm{H}_{1} \\
\text { accepted. There is } \\
\text { a direct positive } \\
\text { influence of } \\
\text { Transformational } \\
\text { Leadership }\left(\mathrm{X}_{1}\right) \text { to } \\
\text { Work } \\
\text { Commitment }\left(\mathrm{X}_{4}\right)\end{array}$ \\
\hline$X_{2}$ to $X_{4}$ & $\begin{array}{c}\rho_{42}=0 \\
, 310\end{array}$ & 3,177 & 1,66 & $\begin{array}{l}\mathrm{H}_{0} \text { is rejected, } \mathrm{H}_{1} \\
\text { accepted. There is } \\
\text { a direct effect of } \\
\text { the positive work } \\
\text { culture }\left(\mathrm{X}_{2}\right) \text { to } \\
\text { Work } \\
\text { Commitment }\left(\mathrm{X}_{4}\right)\end{array}$ \\
\hline$X_{3}$ to $X_{4}$ & $\begin{array}{c}\rho_{43}=0 \\
, 2228\end{array}$ & 2,306 & 1,66 & $\begin{array}{l}\mathrm{H}_{0} \text { is rejected, } \mathrm{H}_{1} \\
\text { accepted. There is } \\
\text { a direct positive } \\
\text { influence Self } \\
\text { Learning }\left(\mathrm{X}_{3}\right) \text { to } \\
\text { Work } \\
\text { Commitment }\left(\mathrm{X}_{4}\right)\end{array}$ \\
\hline
\end{tabular}

TABLE I, Cont.

\begin{tabular}{|c|c|c|c|c|}
\hline$X_{1}$ to $X_{3}$ & $\begin{array}{c}\rho_{31}=0 \\
, 252\end{array}$ & 2,465 & 1,66 & $\begin{array}{l}\mathrm{H}_{0} \text { is rejected, } \mathrm{H}_{1} \\
\text { accepted. There is } \\
\text { a direct positive } \\
\text { influence of } \\
\text { Transformational } \\
\text { Leadership }\left(\mathrm{X}_{1}\right) \text { to } \\
\text { Self Learning }\left(\mathrm{X}_{3}\right)\end{array}$ \\
\hline$X_{2}$ to $X_{3}$ & $\begin{array}{c}\rho_{32}=0 \\
, 230\end{array}$ & 2,248 & 1,66 & $\begin{array}{l}\mathrm{H}_{0} \text { is rejected, } \mathrm{H}_{1} \\
\text { accepted. There is } \\
\text { a direct effect of } \\
\text { the positive work } \\
\text { culture }\left(\mathrm{X}_{2}\right) \text { to } \\
\text { Self Learning }\left(\mathrm{X}_{3}\right)\end{array}$ \\
\hline$X_{1}$ to $X_{2}$ & $\begin{array}{c}\rho_{21}=0 \\
, 266\end{array}$ & 2,605 & 1,66 & $\begin{array}{l}\mathrm{H}_{0} \text { is rejected, } \mathrm{H}_{1} \\
\text { accepted. There is } \\
\text { a direct positive } \\
\text { influence of } \\
\text { Transformational } \\
\text { Leadership }\left(\mathrm{X}_{1}\right) \text { to } \\
\text { Work Culture }\left(\mathrm{X}_{2}\right)\end{array}$ \\
\hline
\end{tabular}

The results of the study showed that the empirical hypotheses: (1) The increasing of transformational leadership is done by a leader and gives its impact to performance. In this case, the principal as a leader in school can motivate teachers in learning activities in schools, principals set a good example in terms of leadership in the school, and principals working with teachers to improve the quality of learning and performance of teachers in the school; (2) The increase in institutional work culture gives impact on performance. Principals can do cooperation among teachers; the principal activity of teachers group discussions on a regular basis; principals can motivate teachers to be able to complete the task in hand in a professional and responsible; principals create a healthy work environment, safe and comfortable as well as transparency in the learning process in the school; (3) Improved self-learning will have an impact on performance. Principals can analyze the needs of each teacher to create a sense of togetherness in improving teacher performance; principals can help teachers to select learning materials or study the teaching materials; and principals can be directed to apply the results of teacher learning during this time; (4) Increased commitment to work in the institutions will have an impact on performance. School principals remind the teachers to aim together; principals give the initiative to the teachers to organize teaching materials; making the strategies and methods of teaching; determine the learning resources; designing and implementing learning evaluation; (5) The increase in transformational leadership will have an impact on work commitment. In this case the principal as a role model seeks to improve the learning activities that already exist; principals can provide motivation to the teachers in the learning process in the school; recalls its principals shared goals in education and foster a work commitment of teachers; (6) Increase in work culture will have an impact on work commitment. Principals should be 
able to create a work atmosphere that is safe, comfortable and full transparency in the learning process in the school; principals cooperate with teachers to determine educational goals; principals involve teachers in the process of making strategies and learning methods in schools; (7) Improved self-learning will have an impact on work commitment. Principals should gives initiative to better learning; principals can teach teachers to analyze personal needs in an effort to increase the capability itself; selecting learning materials or study the teaching materials; and apply the results in an optimal learning; (8) Improved transformational leadership will have an impact on self learning. The headmaster motivate teachers to improve their capabilities are; gave the initiative to prepare for the relevant teaching materials; selecting learning resources and work with teachers to improve the quality of learning in schools; (9) The increase in the work culture will have an impact on self learning. The headmaster create a good working atmosphere and get used to the teachers to cooperate; principals require discussion activity in the school environment; principals provide direction for teachers to do their duties optimally; the principal gives the initiative to continue to improve the capability of teachers in the learning process; (10) The increase in transformational leadership will have an impact on the work culture. The headmaster improve learning activities; motivating teaching and learning activities; creates a safe atmosphere and comfortable work and cooperation with teachers to improve the quality of learning in schools.

\section{CONCLUSION}

Based on the analysis and discussion of the effect of transformational leadership, work culture, self learning and work commitment to teacher performance in State Junior High Schools in Depok can be summarized as follows: (1) Transformational leadership has a direct positive impact on teacher performance. This means an increase of transformational leadership change will cause an increase in the performance of State school teachers in Depok. (2) Work culture has a positive direct impact on teacher performance. This means an increase in work culture change will cause an increase in the performance of State school teachers in Depok. (3) Self learning has a positive direct impact on teacher performance. This means that changes in the increase in self-learning will lead to an increase in the performance of State school teachers in Depok. (4) Work commitment has a positive effect on teacher performance. This means that changes in the increase of work commitments will lead to an increase in the performance of State school teachers in Depok. (5) Transformational leadership has a direct positive effect on work commitments. This means an increase of transformational leadership change will cause an increase in teachers' work commitment at State Junior High School in Depok. (6) Work culture has a positive direct effect on work commitments. This means an increase in work culture change will cause an increase in teachers' work commitment at State Junior High School in Depok. (7) Self learning has a positive direct effect on work commitments. This means that changes in the increase in self-learning will lead to an increase in teachers' work commitment at State Junior High School in Depok. (8) Transformational leadership has a direct effect on self learning. This means an increase of transformational leadership change will lead to an increase in self-learning teacher at State Junior High School in Depok. (9) Work culture has a direct effect on self learning. This means that changes in work culture improvement will lead to an increase in self-learning teacher at State Junior High School in Depok. (10) Transformational leadership has a directly influence to work culture. This means an increase of transformational leadership change will cause an increase in teachers' work culture at State Junior High School in Depok.

Thus transformational leadership, workplace culture, self learning and work commitments should be enhanced and improved so that the performance of the teacher can give the optimal contribution to the development and advancement of education in the city of Depok.

The steps that must be made in improving teacher performance: First, transformational leadership of principals should be focused on open communication about the regulation, the work program agreed upon so that teachers can plan and have a target to develop themselves in a creative and innovative, such as raising the functional position and increase science. Furthermore, leadership support and motivate teachers to improve their performance. Second, school members have a work culture which respects the values of honesty, discipline, hard work, responsive to change and ethics in attitude, direction, critical analytical thinking and innovative in learning activities at school and outside of school. Third, self learning teachers need to be repaired professionally include mastery learning materials as well as mastery of the structure and scientific methodology through training, seminars, as well as adding depth of knowledge. Fourth, work commitment between management and teachers need to be woven so as to foster the commitment of teachers to the achievement of the vision and mission of the school.

\section{ACKNOWLEDGMENT}

The author would like to thank the Public Junior High Schools in Depok for the cooperation and the willingness to be the location of the research. Hopefully, the later development stages can run well and have impact on the education quality services.

\section{REFERENCES}

[1] Robbins, Stephen. H. (2003). Orgnizational Behavior: Concept and Application. (New Jersey: Prentice Hall).

[2] Acua, Christopher F. \& Robert Lussier. (2010). Effective Leadership. Canada: Cengage Learning. 
[3] Meyer, John P. \& Elyse P. Maltin. (2010). Employee Commitment and Well-Being: A Critical Review, Theoritical Framework and Research Agenda (Journal of Vocational Bhavioral, Vol. 77).

[4] Woolfolk, Anita. (2007). Education Psychology. Boston: Pearson.

[5] Yukl, Gary (2001). Leadership in Organization. Fifth Edition. New Jersey: Prentice Hall, Inc.

[6] Viswesvaran, Chockalingan. (2011). Assesment of Individual Job Performance: A Review of the Past Cntury and a Look Ahead, Handbook of Industrial, Work \& Organizational Psychology. London: SAGE Publication.

[7] Baltzac, Stephen. R. (2011). Organizational Development. USA: McGraw-Hill.

[8] Jex, Steve M and Thomas W. Britt (2008). Organizational Psychology: A. Scientist-Practionioner Approach. New Jersey:John Wileys \& Sons, Inc.

[9] Abdaour, Ali Abaas and Ikhlas Altarawneh (2014). Employee Engagement and Organizational Commitment: Evidence Jordan (International Journal of Business, Vol. 19, No. 2).

[10] Wolters. (1998). Educational Psychology. Toronto, CA: Pearson.

[11] Avolio, Bruce J. \& Bernard M. Bass. (2008). Developing Potential Across A Full Range of Leadership: Cases on Transactional and Transformational Leadership. New Jerey: Lawrence Erlbaum Associates Publishers.

[12] Boyer, Naomi and Maxime Kelly. (2005). Breaking The International Mold: Blended Instruction, Self-Direction, And Multi Level Adult Education. (International Jurnal of Self-Directed Learning, Vol. 2. No.1).

[13] Schermerhorn, John R, et,al (2010). Introduction To Management. New York: John wiley \& Son.

[14] Pintrich, R.R. (2002). Motivation in Education: Theory, Research and Application. New Jersey: Merill/Prentice-Hall.

[15] Schein, Edgar H. (2004). Organization Culture. San Fransisco: Jossey-Bass.

[16] Sonnentag, Sabine and Michael Frese. (2002). Psychological Management of Individual Performance. New Jersey: John Wiley \& Son, Ltd.)

[17] Zimmerman, B.J. (2002). Becoming a Self-Regulated Learner: An Overview. Theory Into Practice. New York: Cambridge University Press.

[18] Rothwell, William J and H.C. Kazanaz. (2003). The Strategic Development of Talent: A Framework for Using Talent to Support Yur Organizational Strategy. Amherst: HRD Press.

[19] Givens, Roger J. (2008). Transformmational Leadership: The Impact on Organizational and Personal Outcomes. (Emerging Leadership Journeys, Vol. 1)

[20] Sinha, Smrita dkk. (2010). Impact of Work Culture on Motivation and Performance Level of Employees in Private Sector Companies (Jornal Acta Oeconomica Pragensia, Vol. 18)

[21] Darmayanti, Tri. (2008). Efektifitas Intervensi Ketrampian Self-Regulated Learning dan Keteladanan Dalam Meningkatkan Kemampuan Belajar Mandiri dan Prestasi Belajar Mahasiswa Jarak Jauh. Jurnal Terbuka dan Jarak Jauh, Vol. 9, No. 2.

[22] Naquin, Sharon S and Elwood F. Holton III. (2002) The Effect of Personallity, Affectivity and Work Commitment on Motivation to Improve Work Through Learning (Human Resources Development Quarterly, Vol. 13, No. 4). 